\author{
mgr Magdalena TEKIEŃ \\ Wydział Ekonomii i Zarządzania, Uniwersytet w Białymstoku \\ e-mail:m.tekien@uwb.edu.pl \\ dr Katarzyna LEWKOWICZ-GRZEGORCZYK \\ Wydział Ekonomii i Zarządzania, Uniwersytet w Białymstoku \\ e-mail: k.grzegorczy@uwb.edu.pl
}

DOI: $10.15290 /$ ose.2017.06.90.14

\title{
INSTRUMENTY POCHODNE JAKO NARZĘDZIE OGRANICZANIA RYZYKA WALUTOWEGO W POLSKICH PRZEDSIĘBIORSTWACH
}

\begin{abstract}
Streszczenie
Wzrost umiędzynarodowienia działalności gospodarczej przedsiębiorstw w Polsce prowadzi do większej ekspozycji tych podmiotów na ryzyko zmiany kursów walut obcych. Pojawienie się tego rodzaju ryzyka wymusza stosowanie odpowiednich metod służących jego ograniczeniu. Celem artykułu jest ocena powszechności występowania ryzyka walutowego w polskich przedsiębiorstwach wraz $\mathrm{z}$ analizą skali wykorzystania pozagiekdowych i giełdowych instrumentów pochodnych do zabezpieczenia się przed negatywnymi konsekwencjami zmian kursów walutowych. Realizacji wyznaczonego celu posłużyła analiza literatury przedmiotu oraz danych statystycznych, które zostały udostępnione przez Narodowy Bank Polski oraz Główny Urząd Statystyczny. Na podstawie dostępnych danych statystycznych stwierdzono, iż wykorzystanie walutowych instrumentów pochodnych zależy z jednej strony od poziomu oraz zmienności kursów walutowych, a z drugiej strony od poziomu aktywności polskich przedsiębiorstw na rynkach zagranicznych, głównie w zakresie wymiany handlowej. Najczęściej wykorzystywanymi instrumentami pochodnymi, które przyczyniają się do zmniejszenia ekspozycji na ryzyko walutowe, są kontrakty forward. Wynika to z możliwości dostosowania warunków tych transakcji do potrzeb danego przedsiębiorstwa oraz większej łatwości ich stosowania w porównaniu z innymi instrumentami pochodnymi.

Wartością dodaną niniejszego artykułu jest kompleksowa analiza ryzyka kursowego występujaccego w przedsiębiorstwach w Polsce w latach 2007-2016 wraz z przedstawieniem stopnia wykorzystania walutowych instrumentów pochodnych do ograniczenia ekspozycji na to ryzyko.
\end{abstract}

Słowa kluczowe: ryzyko walutowe, kurs walutowy, instrument pochodny, kontrakt forward, kontrakt futures, opcja walutowa, transakcje CIRS, import, eksport 


\title{
DERIVATIVES AS HEDGING INSTRUMENTS AGAINST FOREIGN EXCHANGE RISK IN POLISH ENTERPRISES
}

\begin{abstract}
Summary
Increasing involvement of companies from Poland in international markets leads to greater currency risk exposure in these entities. This forces enterprises to use appropriate hedging strategies to reduce this risk. The purpose of this paper is to assess the prevalence of currency risk faced by Polish companies and to analyse the extent in which over-the-counter derivatives and stock exchange derivatives are used to protect companies against this risk. The authors present a review of the literature and relevant statistical data published by the National Bank and the Central Statistical Office of Poland. Based on this database, the authors demonstrate that the use of derivatives depends on the levels and fluctuations of currencies, as well as the involvement of Polish companies in international markets, especially in terms of external trade. Moreover, the analysis proves that forward contracts are the most frequently used derivatives to reduce exposure to foreign exchange risk. This is because the conditions of this type of transactions can be adjusted to the requirements and needs of enterprises. These instruments are also easier to use than other derivatives.

The added value of this paper is a comprehensive analysis of the exchange rate risk in Polish companies in 2007-2016, accompanied by a presentation of the scale on which derivatives are used to hedge against currency risk.
\end{abstract}

Key words: foreign exchange risk, currency, derivative, forwards, futures, currency option, CIRS transactions, export, import

JEL Classification: G1,G23, F31,

\section{Wstęp}

Każda działalność gospodarcza wiąże się z koniecznością podejmowania różnego rodzaju decyzji, choć przedsiębiorstwa nie posiadają pełnej informacji na temat czynników wpływających na wybór wariantu decyzyjnego oraz konsekwencji dokonanego wyboru, co sprawia, że są narażone na ryzyko.

Ryzyko można zdefiniować jako sytuację, w której podmiot podejmujący decyzję nie jest w stanie przewidzieć przyszłych zdarzeń z całkowita pewnością. Istnieje zatem niebezpieczeństwo uzyskania wyniku innego niż oczekiwany, gdyż wybrany wariant decyzyjny może doprowadzić do powstania korzyści mniejszych niż spodziewane bądź też straty. Podejmujący decyzję zna jednak możliwe efekty podjętej decyzji oraz prawdopodobieństwo ich pojawienia się. Ta cecha odróżnia ryzyko od niepewności, w której nie można zmierzyć prawdopodobieństwa pojawienia się w przyszłości określonych konsekwencji [Szyszko, 2003, s. 30-32].

Źródła ryzyka, występującego w działalności gospodarczej, są zróżnicowane, co pozwala na wskazanie wielu kryteriów klasyfikacji tego zjawiska. Wśród nich można wyróżnić czynniki kształtujące ryzyko. Według tego kryterium można wymienić:

- ryzyko specyficzne (tzw. wewnętrzne) - wynikające z działalności danego podmiotu gospodarczego i znajdujące się pod jego kontrola, co oznacza, że jego źródłem może być m.in. sposób zarządzania firmą lub czynniki o charakterze finansowym (np. spadek płynności finansowej czy wzrost kosztu kapitału obcego); w ramach tego rodzaju wyodrębnia się ryzyko: niedotrzymania 
warunków, zarządzania, biznesu, finansowe, bankructwa, płynności, zmiany ceny, reinwestowania, wykupu na żądanie oraz zmienności;

- $\quad$ ryzyko systemowe (tzw. rynkowe) - powstające w rezultacie wystapienia czynników zewnętrznych, na które przedsiębiorstwo nie ma wpływu i nie może ich wyeliminować, np.: działanie sił przyrody, decyzje polityczne czy globalne uwarunkowania ekonomiczne (m.in.: inflacja oraz zmiany stóp procentowych, kursów walutowych lub stóp zwrotu z inwestycji w akcje); zalicza się do niego:

- $\quad$ ryzyko stopy procentowej;

- ryzyko rynku;

- $\quad$ ryzyko siły nabywczej;

- ryzyko polityczne;

- $\quad$ ryzyko wydarzeń;

- $\quad$ ryzyko walutowe (tzw. kursowe), w tym: ryzyko księgowe, ryzyko transakcyjne, ryzyko ekonomiczne [Kalinowski, 2012, s. 13-16].

W niniejszym artykule analizie zostało poddane ryzyko walutowe. W literaturze przedmiotu pojęcie to definiuje się jako prawdopodobieństwo zmiany dochodu w wyniku nieoczekiwanych wahań kursów walutowych. Ma ono miejsce wówczas, gdy moment powstania należności lub zobowiązania denominowanego w walucie obcej jest inny niż termin ich realizacji. Konsekwencją pojawiającej się wówczas rozbieżności w czasie między powstaniem a uregulowaniem rozrachunków może być spadek wartości należności bądź wzrost wartości zobowiązania w przeliczeniu na walutę krajową [Kalinowski, 2012, s. 36-37].

Próbę zdefiniowania ryzyka walutowego podjął również D. Bennett, według którego ekspozycja na ryzyko zmiany kursów walutowych obejmuje:

- pozycje bilansu, które są wyrażone w walutach obcych;

- $\quad$ rzeczywistą i fizyczną sprzedaż oraz zakupy dóbr i usług, gdy nie zostały one jeszcze zafakturowane;

- $\quad$ transakcje kupna i sprzedaży przyszłych okresów, np. kontrakty długoterminowe na nabycie rzeczowych aktywów trwałych;

- $\quad$ rachunki i płatności wyrażone w walucie innej niż krajowa, pojawiające się w momencie zawarcia transakcji handlowej [Bennett, 2000, s. 28-29].

Przedsiębiorstwo jest narażone na ryzyko walutowe w trzech obszarach jego działalności, co daje podstawę do dokonania jego klasyfikacji. Zgodnie z tym kryterium, wskazuje się:

- $\quad$ ryzyko księgowe (tzw. ryzyko przeliczeniowe lub bilansowe) - występuje w obszarze finansowo-księgowym i jest związane z powstaniem różnic kursowych podczas wyceny bilansowej składników aktywów i pasywów denominowanych w walutach obcych albo konsolidacji sprawozdań finansowych międzynarodowych grup kapitałowych;

- $\quad$ ryzyko transakcyjne - pojawia się w bieżących transakcjach handlowych i finansowych oraz dotyczy rozbieżności w czasie między datą zawarcia kontraktu rozliczanego w walucie innej niż krajowa a momentem ujęcia przychodów lub kosztów z tego tytułu bądź też otrzymania płatności z zawartej umowy; 
- $\quad$ ryzyko ekonomiczne - jest związane z działalnością operacyjna przedsiębiorstwa i wynika ze zmienności kursów walutowych, co skutkuje nieprzewidywalnością zmian oczekiwanych w przyszłości strumieni pieniężnych, tj.: planowanych przychodów, kosztów i przepływów pieniężnych [Ożga, 2016, s. 6-7].

Powszechność występowania ryzyka walutowego przede wszystkim wiąże się z rosnącą ilością przedsiębiorstw, które zdecydowały się na internacjonalizacje prowadzonej działalności i dokonywanie rozliczeń w walucie innej niż waluta krajowa. Podmiotami narażonymi na ryzyko kursowe są zatem szczególnie eksporterzy i importerzy, w przypadku gdy wpływy ze sprzedaży dóbr i usług za granicę oraz wydatki na import są denominowane w walucie obcej. Poza tym, ryzyko walutowe ma miejsce w jednostkach będących uczestnikami międzynarodowego przepływu kapitału. Podmiotami ryzyka kursowego są wówczas przedsiębiorstwa, które dokonują bezpośrednich lub pośrednich inwestycji kapitałowych albo posiadają zadłużenie obsługiwane w walucie obcej.

\section{Ekspozycja polskich przedsiębiorstw na ryzyko walutowe}

Negatywne konsekwencje, będące efektem niepożądanych zmian kursu walutowego, są wskazywane jako jedne z głównych ograniczeń w rozwoju przedsiębiorstw w Polsce. Potwierdzają to prowadzone przez NBP kwartalne badania ankietowe koniunktury, które są zawarte w tabeli 1.

TABELA 1.

\section{Bariery rozwoju przedsiębiorstw w Polsce w latach 2007-2015 - wyniki ankiety Narodowego Banku Polskiego}

\begin{tabular}{|l|c|c|c|c|c|c|c|c|c|c|}
\hline \multirow{2}{*}{\multicolumn{2}{c|}{ Wyszczególnienie* }} & \multicolumn{9}{c|}{ Miejsce w rankingu } \\
\cline { 2 - 13 } & $\mathbf{2 0 0 7}$ & $\mathbf{2 0 0 8}$ & $\mathbf{2 0 0 9}$ & $\mathbf{2 0 1 0}$ & $\mathbf{2 0 1 1}$ & $\mathbf{2 0 1 2}$ & $\mathbf{2 0 1 3}$ & $\mathbf{2 0 1 4}$ & $\mathbf{2 0 1 5}$ & $\mathbf{2 0 1 6}$ \\
\hline Niski popyt & 6. & 1. & 1. & 1. & 1. & 1. & 1. & 1. & 4. & 4. \\
\hline Wahania i poziom kursów walutowych & 1. & 3. & 2. & 2. & 2. & 3. & 4. & 5. & 5. & 1. \\
\hline Wysoka konkurencja & 5. & 5. & 3. & 4. & 6. & 7. & 5. & 2. & 3. & 6. \\
\hline Zatory płatnicze i niska płynność & brak & 4. & 4. & 5. & 4. & 2. & 2. & 4. & 7. & 8. \\
\hline Wzrost cen surowców i materiałów & 3. & 4. & 5. & 3. & 3. & 6. & brak & brak & 8. & 7. \\
\hline Zmiany podatków i przepisów & 7. & brak & 6. & brak & brak & 4. & 3. & brak & 1. & 2. \\
\hline Wysoka niepewność działalności & brak & 6. & brak & 6. & 5. & brak & brak & 3. & 2. & 3. \\
\hline
\end{tabular}

* - Dane w tabeli 1. zawierają bariery rozwoju najczęściej wskazywane przez polskie przedsiębiorstwa w latach 2007-2016 w badaniu ankietowym NBP dotyczacym analizy sytuacji sektora przedsiębiorstw (S $S_{z y b k i}$ Monitoring NBP).

Źródło: opracowanie własne na podstawie danych NBP: [http://www.nbp.pl/home.aspx?c=/ ascx/koniunktura_prezentacja.ascx].

Analiza danych NBP na temat barier rozwoju tych podmiotów potwierdza to, iż w latach 2007-2016 wahania i poziom kursów walutowych były wskazywane jako istotny 
czynnik uniemożliwiający ekspansję polskich przedsiębiorstw na rynku krajowym i międzynarodowym. W badanym okresie ten czynnik ograniczający najczęściej zajmował 2. pozycję (trzykrotnie) w rankingu. Poza tym, dwukrotnie został wskazany jako najważniejsza bariera rozwoju. Tylko niski popyt na rynku był częściej wskazywany jako główny czynnik ograniczający rozwój przedsiębiorstw w Polsce (siedmiokrotnie na 1. miejscu w rankingu).

Ryzyko kursowe jest związane zarówno z kształtowaniem poziomu kursu walutowego, jak i jego wahaniami. Do walut, które w największym stopniu przyczyniają się do powstania ryzyka walutowego w polskich przedsiębiorstwach, przede wszystkim zalicza się: EUR, USD, JPY i GBP ${ }^{1}$. Notowania średnioważonych kursów tych walut obcych względem PLN w poszczególnych miesiącach zostały przedstawione na rysunku 1.

RYSUNEK 1.

\section{Notowania wybranych kursów walutowych względem PLN w latach 2007-2016}

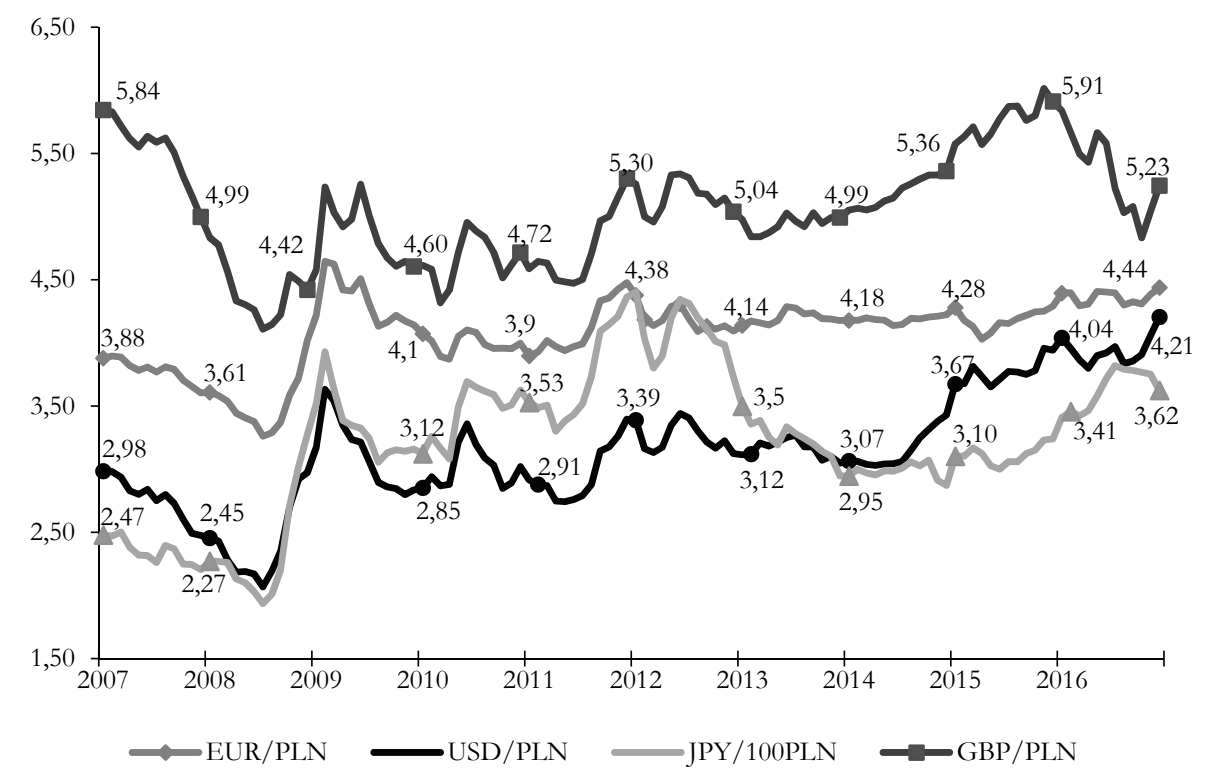

Źródło: opracowanie własne na podstawie danych NBP: [http://www.nbp.pl/home.aspx? $\mathrm{f}=/$ kursy $/$ arch_a.html].

Na podstawie analizy danych (rysunek 1.) można stwierdzić, że od sierpnia 2007 roku do lipca 2008 roku nastapiła znaczna aprecjacja złotego względem walut obcych, co było spowodowane silnym uzależnieniem polskiej waluty od sytuacji na światowym

1 Do analizy wybrano cztery waluty, których udział w obrotach na światowym rynku FOREX, według raportu [Triennial Central Bank Survey..., 2016, s. 10], był najwyższy, tj.: 87,6\% - USD; 31,3\% - EUR; 21,6\% - JPY i 12,8\% - GBP (suma udziałów poszczególnych walut w obrotach na tym rynku wynosiła $200 \%$, gdyż w każdą transakcję były zaangażowane dwie waluty). 
rynku finansowym. Kursy analizowanych walut obcych uległy obniżeniu od około 14\% w przypadku EUR/PLN do ponad 26\% w przypadku USD/PLN i GBP/PLN, osiagając na koniec tego okresu minimalny poziom. Trend wzrostowy wartości złotego odwrócił się w kolejnych miesiącach. Od września 2008 roku do lutego 2009 roku można było zaobserwować deprecjację złotego oraz wzrost zmienności jego kursu w wyniku niepewności związanej ze skalą spowolnienia gospodarczego w Polsce na skutek kryzysu finansowego na świecie. Dowodem tego był spadek wartości złotówki o 41,2\% wobec EUR; $65,6 \%$ w stosunku do USD; $95,57 \%$ wobec JPY oraz $26,26 \%$ w przypadku GBP.

Od lutego 2009 roku do kwietnia 2010 roku miał miejsce ponowny wzrost wartości złotego w odniesieniu do analizowanych walut obcych o około $70 \mathrm{gr}-80 \mathrm{gr}$, po czym wahania kursów tych walut ustabilizowały się i na przestrzeni kolejnych 12 miesięcy, tj. do maja 2011 roku, zmieniły się od 2\% (EUR/PLN) do 16\% (JPY/PLN). Po względnej stabilizacji na rynku walut zaszły kolejne wahania kursów walutowych. Potwierdziły to czterokrotne zmiany kierunku trendu wartości złotego w okresie od czerwca 2011 roku do czerwca 2013 roku.

Analiza średnioważonych kursów walut obcych od lipca 2013 roku do końca 2016 roku pozwala zaobserwować względne ustabilizowanie kursu EUR/PLN w tym okresie. Kształtował się on w przedziale 4,02 zł - 4,43 zł, przy widocznej aprecjacji złotego w I połowie 2015 roku. Wyższą zmienność niż kurs EUR/PLN wykazywał USD/PLN, który w tym okresie wahał się w przedziale od 2,87 zł do 3,82 zł. Wynikało to z osłabienia kursu euro względem dolara amerykańskiego w związku z rozbieżnością pomiędzy polityką pieniężną prowadzoną przez Rezerwę Federalną i Europejski Bank Centralny [Rožwój..., 2016, s. 289]. Relatywnie duże wahania wykazywał również kurs GBP/PLN, czego dowodzi wzrost tego kursu z 4,96 zł w lipcu 2013 roku do 6,01 zł w listopadzie 2015 roku i odwrócenie tendencji wzrostowej w 2016 roku. Było to spowodowane m.in. rozpoczęciem procesu wystąpienia Wielkiej Brytanii z Unii Europejskiej i osłabieniem funta brytyjskiego w stosunku do walut obcych.

Podsumowując, w okresie od stycznia 2007 roku do końca 2016 roku największą zmienność wykazywał kurs JPY/PLN, następnie USD/PLN i GBP/PLN, a najmniejszą kurs EUR/PLN. Świadczą o tym współczynniki zmienności, które zostały obliczone na podstawie danych dotyczących średnioważonych kursów wybranych walut obcych w ujęciu miesięcznym w badanym okresie. Wynosiły one odpowiednio: 17,9\%; 14,5\%; $8,8 \%$ i $6,7 \%$.

Porównując wyniki analizy danych z tabeli 1 . i rysunku 1. można zauważyć, że wahania i poziom kursów walutowych były wskazywane jako jedne z najważniejszych barier rozwoju w okresach, w których występowała wysoka zmienność kursów walutowych. Wysokie miejsce w rankingu czynnik ten zajmował w latach 2007-2011, w których miały miejsce znaczne wahania kursów walutowych. Od 2012 roku do 2015 roku zmalało znaczenie wahań i poziomów kursów walutowych jako bariery rozwoju przedsiębiorstw, gdyż wyróżniał je stosunkowo stabilny poziom. Kurs walutowy jako najistotniejsza bariera rozwoju polskich przedsiębiorstw ponownie został wskazany w 2016 roku, w którym były zauważalne większe wahania cen walut obcych wyrażonych w PLN. 
Oczekiwania polskich przedsiębiorców związane z poziomem kursów walut obcych są uzależnione od tego, czy posiadają oni aktywa, czy też pasywa w walutach obcych. W przypadku eksporterów oraz posiadaczy aktywów zagranicznych korzystny będzie spadek wartości waluty krajowej względem walut obcych, a to oznacza, że będą oni zabezpieczali się przed aprecjacją waluty krajowej w celu utrzymania opłacalności na odpowiednim poziomie. $Z$ kolei, importerzy i podmioty posiadające zobowiazania wobec zagranicy będą oczekiwali umocnienia pieniądza krajowego i zabezpieczali się przed deprecjacja złotego. Jednak w obu przypadkach istnieją niekorzystne duże wahania kursów walutowych i ich nieprzewidywalność, co generuje ryzyko walutowe w przedsiębiorstwie.

TABELA 2.

Wybrane pozycje powodujące wzrost ekspozycji polskich przedsiębiorstw na ryzyko walutowe w latach 2007-2016

\begin{tabular}{|c|c|c|c|c|c|c|}
\hline \multirow[b]{2}{*}{ Rok } & \multirow[b]{2}{*}{$\begin{array}{c}\text { Import } \\
\text { ogółem } \\
\text { (w mld zł) }\end{array}$} & \multirow[b]{2}{*}{$\begin{array}{c}\text { Eksport } \\
\text { ogółem } \\
\text { (w mld zł) }\end{array}$} & \multirow{2}{*}{$\begin{array}{c}\text { W tym: } \\
\text { eksport } \\
\text { w podmiotach } \\
\text { niefinanso- } \\
\text { wych }^{3} \\
\text { (w mld zX) }\end{array}$} & \multirow[b]{2}{*}{$\begin{array}{l}\text { Zadłużenie } \\
\text { zagraniczne } \\
\text { w pozosta- } \\
\text { łych sekto- } \\
\text { rach }^{2} \\
\text { (w mld zł) }\end{array}$} & \multicolumn{2}{|c|}{ W tym: } \\
\hline & & & & & $\begin{array}{c}\text { kredyty } \\
\text { i po- } \\
\text { życzki } \\
\text { (w mld zł) }\end{array}$ & $\begin{array}{c}\text { kredyty } \\
\text { handlowe } \\
\text { (w mld zł) }\end{array}$ \\
\hline 2007 & 456,8 & 386,6 & 365,49 & 145,45 & 88,19 & 40,49 \\
\hline 2008 & 497,0 & 405,4 & 376,78 & 198,37 & 128,85 & 48,24 \\
\hline 2009 & 463,4 & 423,2 & 384,75 & 206,32 & 134,72 & 47,44 \\
\hline 2010 & 536,2 & 481,1 & 440,42 & 176,59 & 125,34 & 45,29 \\
\hline 2011 & 623,4 & 558,7 & 531,84 & 210,09 & 145,82 & 55,74 \\
\hline 2012 & 648,1 & 603,4 & 573,86 & 197,25 & 139,37 & 49,83 \\
\hline 2013 & 656,1 & 647,9 & 602,59 & 193,65 & 134,71 & 51,54 \\
\hline 2014 & 704,6 & 693,5 & 628,82 & 202,32 & 140,08 & 52,22 \\
\hline 2015 & 741,0 & 750,8 & 652,87 & 207,57 & 143,60 & 54,72 \\
\hline 2016 & 777,5 & 798,2 & bd. & 222,58 & 149,90 & 62,24 \\
\hline
\end{tabular}

Źródło: opracowanie własne na podstawie danych GUS: [http://stat.gov.pl/].

Pojawienie się rozliczeń w walucie obcej naraża przedsiębiorstwo na ryzyko walutowe, którego wystąienie może pociagać za sobą negatywne konsekwencje w postaci pogorszenia wyników finansowych. Analiza danych z tabeli 2. potwierdza, że poziom ekspozycji na ryzyko kursowe był coraz wyższy. Polskie podmioty rozszerzały działalność na rynkach międzynarodowych, czego dowodzi m.in. wzrost obrotów handlowych z zagranica. W latach 2007-2016 wartość importu wzrosła o 320,7 mld zł, ti. o około 70\%, a eksport zwiększył się ponad dwukrotnie z 386,6 mld zł do 798,2 mld zł. Na wysokim poziomie utrzymywało się również zadłużenie zagraniczne w pozostałych sektorach,

2 Pozostałe sektory to podmioty finansowe (inne niż monetarne instytucje finansowe, instytucje ubezpieczeniowe i fundusze emerytalno-rentowe) oraz podmioty niefinansowe (przedsiębiorstwa niefinansowe, gospodarstwa domowe i instytucje niekomercyjne działające na rzecz gospodarstw domowych).

3 Podmioty niefinansowe, w których liczba pracujących wynosiła 10 i więcej osób prowadzących księgi rachunkowe lub podatkową księgę przychodów i rozchodów. 
które wynosiło od 145,45 mld zł w 2007 roku do 222,58 mld zł w 2016 roku. Główną waluta, w której polskie podmioty posiadały dług poza granicami Polski, było euro. Jego udział w walutowej strukturze zadłużenia w latach 2010-2015 był stabilny i wahał się od około 57\% do około 61\%. Drugą walutą rozliczeń był dolar, a jego udział kształtował się w przedziale około $27 \%-31 \%$. W przypadku wystąpienia wahań kursowych pozycja przedsiębiorstw zadłużonych wobec nierezydentów mogła ulec pogorszeniu [Rozwój..., 2016, s. 19-21]. Intensyfikacja zagranicznej wymiany handlowej oraz posiadanie zadłużenia zagranica prowadzi zatem do wzrostu stanu należności i zobowiązań denominowanych w walucie obcej, co w konsekwencji naraża przedsiębiorstwa na wyższe ryzyko zmian kursów walutowych.

\section{Metody zabezpieczenia się przedsiębiorstw przed ryzykiem kursowym}

Ekspozycja na ryzyko zmian kursów walutowych wymaga podjęcia odpowiednich działań mających na celu ograniczenie wpływu wahań kursów walutowych na wyniki przedsiębiorstwa. Jednostka może przyjąć różne postawy wobec ryzyka kursowego w zależności od: jego formy, prawdopodobieństwa wystąpienia czy też wielkości ewentualnych strat.

Do metod zabezpieczenia się przedsiębiorstw przed ryzykiem walutowym, według Loderera i Pichlera [2000, s. 320-321] $]^{4}$, zalicza się:

- zatrzymanie (akceptację) ryzyka - jednostka świadomie decyduje się na ponoszenie negatywnych konsekwencji związanych z pojawieniem się wahań kursów walut;

- $\quad$ unikanie ryzyka - polega na prowadzeniu takiej działalności gospodarczej, przy której ryzyko walutowe nie istnieje lub występuje w najmniejszym możliwym stopniu, np. poprzez dokonywanie płatności wyłącznie w walucie krajowej i przerzucenie ryzyka na partnerów transakcji;

- $\quad$ redukcję ryzyka - ograniczenie prawdopodobieństwa pojawienia się negatywnych konsekwencji ryzyka walutowego dzięki podejmowaniu działań zaradczych, takich jak: utrzymanie zamkniętych pozycji walutowych, wybór waluty kontraktu, stosowanie klauzul waloryzacyjnych czy kompensat rozliczeń z zagranicznymi kontrahentami;

- $\quad$ transfer ryzyka - przeniesienie skutków ryzyka kursowego na inne podmioty, które są w stanie ponieść to ryzyko, pobierając z tego tytułu odpowiednia opłatę, np.: dywersyfikacja ryzyka, ubezpieczenie ryzyka lub hedging.

O wyborze optymalnej metody zabezpieczenia się przed ryzykiem zmian kursów walutowych decyduje wiele czynników. Każde przedsiębiorstwo przed podjęciem decyzji dotyczącej sposobu reakcji na ryzyko walutowe powinno dokonać jego identyfikacji oraz określić poziom ekspozycji danego podmiotu na to ryzyko. Poza tym, wybór odpowiedniej metody zależy od wielkości danego przedsiębiorstwa. Z jednej strony duże podmioty mają większą skłonność do akceptacji ryzyka, a z drugiej posiadają większą

4 Por. [Misztal, 2004, s. 67-77]. 
siłę przetargową w zakresie negocjacji warunków wykorzystania instrumentów pozwalających na redukcję bądź transfer ryzyka. Postawa firmy wobec ryzyka kursowego jest również uzależniona od: kwalifikacji, świadomości i preferencji osób zarządzających, które decydują o sposobie zarządzania ryzykiem walutowym w przedsiębiorstwie.

\section{Instrumenty pochodne jako zabezpieczenie ekspozycji na ryzyko walutowe}

Ryzyko walutowe może być transferowane na inne podmioty za pomocą wielu narzędzi, do których zalicza się m.in. instrumenty pochodne, stanowiące formę pozabilansowych transakcji zabezpieczających ryzyko kursowe.

Zgodnie z przepisami Ustany z dn. 29.07.2005 roku o obrocie instrumentami finansonymi, instrumenty pochodne definiuje się jako: opcje, kontrakty terminowe, swapy, umowy forward oraz inne prawa majątkowe, których cena zależy bezpośrednio lub pośrednio od wartości instrumentu bazowego. Może być nim m.in.: stopa procentowa, indeks albo wskaźnik finansowy oraz cena lub wartość instrumentów finansowych, a wprzypadku zabezpieczenia ryzyka walutowego takim instrumentem bazowym jest waluta obca [Ustawa zdn. 29.07.2005 roku..., 2005].

Kontrakty forward to forma umowy, w której jedna za stron zobowiazuje się do zakupu (pozycja długa) uzgodnionej ilości waluty obcej, a druga strona jest zobligowana do sprzedaży (pozycja krótka) tej waluty po z góry określonej cenie i w ściśle określonym terminie w przyszłości [Misztal, 2004, s. 89-90]. Warunki zawarcia tego kontraktu sa ustalane wyłącznie przez strony, które zawierają umowę, co oznacza, że kontrakt forward to transakcja niestandaryzowana. Jednak konieczne jest, aby cena zawarcia umowy kupna/sprzedaży instrumentu bazowego oraz termin rozliczenia tego instrumentu zostały określone w momencie zawierania kontraktu [Kalinowski, 2012, s. 63-64]. Zabezpieczenie przed ryzykiem zmiany kursów walutowych z wykorzystaniem kontraktów forward polega na zajęciu odwrotnej pozycji w stosunku do pozycji, którą przedsiębiorstwo zamierza zabezpieczyć. Tym samym podmiot zabezpieczający długą pozycję walutową ${ }^{5}$ zajmuje pozycję krótką w kontrakcie forward. Z kolei, przedsiębiorstwo zabezpieczające krótką pozycję walutową ${ }^{6}$ powinno zająć długą pozycję w kontrakcie forward. W rezultacie należności i zobowiązania w walutach obcych zrównają się (zamknięta pozycja walutowa), a strata poniesiona na jednej z tych pozycji powinna zostać skompensowana zyskiem osiagniętym na drugiej pozycji [Misztal, 2004, s. 91-92].

Drugim przykładem instrumentu pochodnego, służącego do transferu ryzyka walutowego, są kontrakty futures. Wiążą się one z zawarciem umowy, w której jedna ze stron zobowiązuje się do zakupu wystandaryzowanej ilości waluty obcej, a druga do jej sprzedaży po określonej cenie i w ściśle ustalonym terminie [Miciuła, 2015, s. 253]. Mechanizm zabezpieczenia zmian kursów walutowych w przypadku kontraktów futures jest analogiczny do działania transakcji forward. Przedsiębiorstwo w tym kontrakcie zajmuje pozycję odwrotną w stosunku do pozycji walutowej, która ma być zabezpieczo-

Należności w walucie obcej przewyższają zobowiązania w tej walucie [Widz, 2012, s. 436].

Zobowiązania w walucie obcej przewyższają należności w tej walucie [Widz, 2012, s. 436]. 
na. Występowanie w kontraktach futures jako strona sprzedająca instrument bazowy pozwala na zabezpieczenie się przed spadkiem kursu waluty obcej, natomiast wzrost ceny waluty zagranicznej można zabezpieczyć poprzez zajęcie pozycji długiej w kontrakcie [Misztal, 2004, s. 93-96]. Stosowanie transakcji futures wymaga spełnienia znacznie większych wymogów niż w przypadku kontraktów forward, gdyż są one dostępne jedynie w obrocie giełdowym. Jednym z takich warunków jest konieczność wniesienia depozytu zabezpieczającego do izby clearingowej, który musi być uzupełniany w trakcie trwania kontraktu [Kalinowski, 2012, s. 67-68].

Transfer ryzyka zmian kursów walutowych jest również możliwy dzięki wykorzystaniu opcji walutowej. Definiuje się ją jako umowę, w której jedna ze stron, tzw. posiadacz opcji, ma prawo do zakupu lub sprzedaży określonej ilości waluty obcej po cenie z góry uzgodnionej oraz w określonym terminie. Drugą stroną umowy jest wystawca opcji, który zobowiązuje się do sprzedaży (w opcji kupna - call) lub zakupu (w opcji sprzedaży - put) tej waluty po z góry określonej cenie i w określonym czasie. W przypadku tego instrumentu pochodnego, posiadacz opcji płaci wystawcy premię w zamian za co otrzymuje prawo, a nie obowiązek dokonania transakcji zakupu/sprzedaży instrumentu bazowego [Kalinowski, 2012, s. 71-73].

Jak wynika z powyższej definicji opcji walutowej, można wskazać opcje call i opcje put. W pierwszej z nich posiadacz opcji uzyskuje prawo do zakupu waluty obcej po określonej cenie i w określonym terminie. Wystawca opcji jest wówczas zobowiązany do sprzedaży określonej ilości tej waluty. Z kolei, opcja put daje posiadaczowi prawo do sprzedaży waluty obcej na warunkach określonych w umowie, a wystawca opcji jest zobligowany do zakupu tej waluty [Sudacevschi, 2017, s. 745]. Nabywając opcję call, przedsiębiorstwo zabezpiecza się zatem przed wzrostem kursu waluty obcej. Zakup opcji pull pozwala natomiast na ograniczenie ryzyka spadku kursu waluty zagranicznej.

Instrumentem pochodnym o innym mechanizmie działania, niż dotychczas omówione, jest swap. Do zabezpieczenia ryzyka zmiany kursu walutowego wykorzystuje się swap walutowy, będący transakcją dwuwalutową. Jego istota polega na tym, że strony umowy zobowiązują się do wymiany między sobą określonej kwoty jednej waluty obcej na równowartość w innej walucie (np. walucie krajowej). Kurs wymiany i termin rozliczenia zostają ustalone w trakcie zawarcia kontraktu swap. W trakcie trwania umowy nie następują płatności odsetek. W momencie zapadalności kontraktu jedna ze stron jest zobowiązana do zwrotu tej samej kwoty w walucie obcej, za co otrzymuje równowartość w walucie, na którą została wymieniona [Kalinowski, 2012, s. 84-86].

Inny rodzaj kontraktu swap, za pomocą którego jest transferowane ryzyko kursowe, to swap walutowo-odsetkowy (Currency Interest Rate Swap-CIRS). Polega on na wymianie kwot kapitału oraz płatności odsetkowych w dwóch różnych walutach pomiędzy dwiema stronami kontraktu. Currency Interest Rate Swap pozwala na wymianę wartości nominalnej pożyczki wraz z jej oprocentowaniem w danej walucie na wartość nominalna pożyczki i jej oprocentowanie w innej walucie [Kalinowski, 2012, s. 88]. 


\section{Analiza stanu wykorzystania instrumentów pochodnych w zarządzaniu ryzykiem walutowym polskich przedsiębiorstw}

Wykorzystanie instrumentów pochodnych w zarządzaniu ryzykiem kursowym w przedsiębiorstwach w Polsce można ocenić na podstawie analizy danych statystycznych NBP dotyczących średnich dziennych obrotów netto na krajowym rynku walutowych instrumentów pochodnych, które zostały zobrazowane na rysunku 2.

RYSUNEK 2.

Średnie dzienne obroty netto na krajowym rynku walutowych instrumentów pochodnych w latach 2007-2015 (w mln zł)

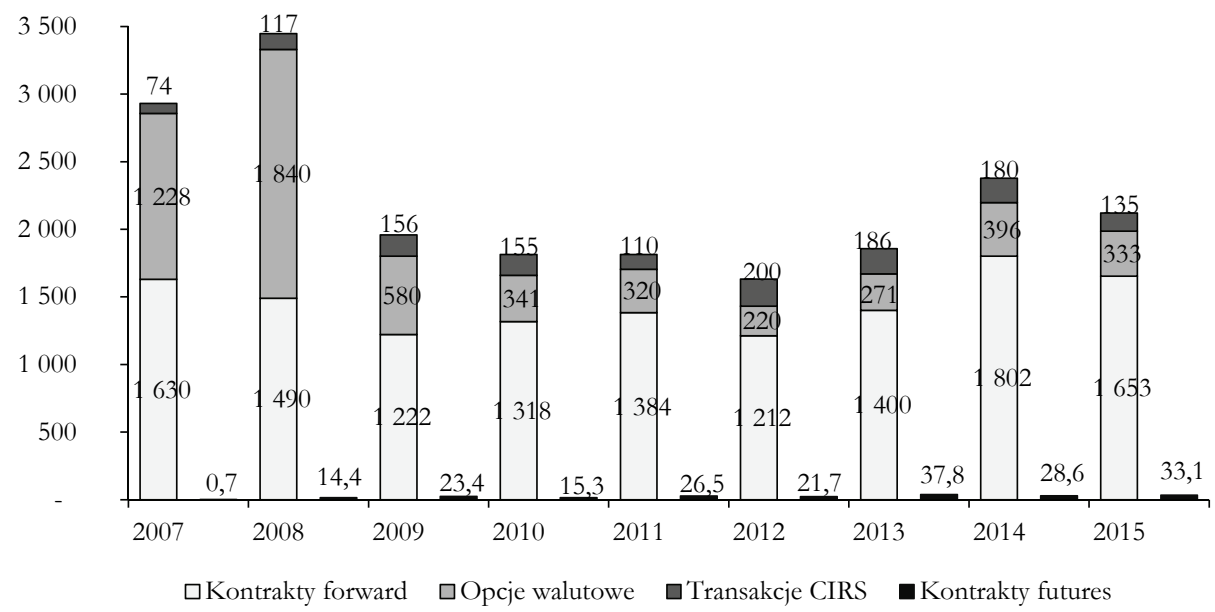

Źródło: opracowanie własne na podstawie danych NBP: [Rozwoój..., 2016, s. 293; 2013, s. 274; 2009, s. 250].

Wykorzystanie pozagiełdowych instrumentów pochodnych, czyli kontraktów forward, opcji walutowych i transakcji CIRS, pozwala na swobodne dostosowanie warunków transakcji do specyfiki działalności danego przedsiębiorstwa. Nie jest to możliwe w przypadku kontraktów futures, które są notowane na GPW S.A. W rezultacie transakcje pozagiełdowe stanowiły niemal 100\% obrotów na krajowym rynku walutowych instrumentów pochodnych, a ich wartość głównie była determinowana przez wykorzystanie kontraktów forward i opcji walutowych.

Średnie dzienne obroty netto na krajowym rynku walutowych transakcji forvvard (tabela 3.) kształtowały się w przedziale 1,49-1,63 mld zł w latach 2007-2008; 1,2-1,4 mld zł w okresie od 2009 roku do 2013 roku oraz 1,65-1,8 mld zł w latach 2014-2015. Wahania poziomu wykorzystania kontraktów forward były zależne m.in. od poziomu zmienności kursów walutowych. Na początku badanego okresu podmioty na rynku walutowym zawierały transakcje forward w celu zabezpieczenia przed silna aprecjacją złotego. Byli to głównie eksporterzy, którzy do zabezpieczenia pozycji walutowych stosowali 
kontrakty forward. W latach 2009-2013 wolumen zawieranych kontraktów ustabilizował się w związku z względnie mniejszymi wahaniami złotówki w porównaniu z wcześniejszym okresem. Kolejny wzrost wykorzystania tych instrumentów pochodnych rozpoczął się od 2013 roku, co było związane z większym zainteresowaniem tymi transakcjami wśród eksporterów i importerów oraz podmiotów posiadających zadłużenie w walucie obcej, a także ze wzrostem zmienności kursów walutowych - zwłaszcza USD/PLN [Rozwoój..., 2015, s. 295-296].

TABELA 3.

Krajowy rynek walutowych kontraktów forward w latach 2007-2015

\begin{tabular}{|c|c|c|c|c|c|c|c|c|c|}
\hline \multirow[t]{2}{*}{ Rok } & \multirow{2}{*}{$\begin{array}{c}\text { Średnie } \\
\text { dzienne } \\
\text { obroty netto } \\
\text { na krajowym } \\
\text { rynku FX } \\
\text { forward } \\
\text { (w mln zł) }\end{array}$} & \multicolumn{2}{|c|}{$\begin{array}{c}\text { W tym: } \\
\text { zawierane przez } \\
\text { przedsiębiorstwa } \\
\text { niefinansowe }\end{array}$} & \multirow[t]{2}{*}{$\begin{array}{c}\text { Udział } \\
\text { w transak- } \\
\text { cjach po- } \\
\text { chodnych } \\
\text { ogółem* } \\
(w \%)\end{array}$} & \multicolumn{2}{|c|}{$\begin{array}{c}\text { Struktura termi- } \\
\text { nowa } \\
(\mathrm{w} \%)\end{array}$} & \multicolumn{3}{|c|}{$\begin{array}{c}\text { Struktura walutowa } \\
(\mathrm{w} \%)\end{array}$} \\
\hline & & $\begin{array}{c}\text { wartość } \\
(\mathrm{w} \text { mln zł) }\end{array}$ & $\begin{array}{l}\text { udział } \\
(w \%)\end{array}$ & & $\begin{array}{l}\text { poniżej } \\
7 \mathrm{dni}\end{array}$ & $\begin{array}{c}\text { powyżej } \\
7 \text { dni }\end{array}$ & EUR & USD & Inne \\
\hline 2007 & 1630 & 1304,0 & 80 & 44,5 & 34,8 & 65,2 & 58 & 24 & 18 \\
\hline 2008 & 1490 & 1221,8 & 82 & 35,3 & 30 & 70 & 55 & 30 & 15 \\
\hline 2009 & 1222 & 1087,6 & 89 & 54,9 & bd. & bd. & 68 & 26 & 6 \\
\hline 2010 & 1318 & 921,7 & 70 & 50,4 & bd. & bd. & 68 & 26 & 6 \\
\hline 2011 & 1384 & 1148,7 & 83 & 62,4 & bd. & bd. & 65 & 30 & 5 \\
\hline 2012 & 1212 & 1030,2 & 85 & 62,3 & 35 & 65 & 64 & 33 & 3 \\
\hline 2013 & 1400 & 1190,0 & 85 & 62,8 & 29,3 & 70,7 & 63 & 33 & 4 \\
\hline 2014 & 1802 & 1261,4 & 70 & 52,4 & 20,5 & 79,5 & 61 & 31 & 8 \\
\hline 2015 & 1653 & 1299,2 & 79 & 60,3 & 21,1 & 78,9 & 58 & 33 & 9 \\
\hline
\end{tabular}

* - Udział średnich dziennych obrotów netto na krajowym rynku transakcji forward zawieranych przez przedsiębiorstwa niefinansowe w średnich dziennych obrotach netto na krajowym rynku instrumentów pochodnych.

bd. - brak danych

Źródło: opracowanie własne na podstawie danych NBP: [http://www.nbp.pl/home.aspx? $\mathrm{f}=$ systemfinansowy/rozwoj.html].

Kontrakty forward zawierane przez przedsiębiorstwa niefinansowe kształtowały obroty nie tylko na krajowym rynku walutowych kontraktów forward, ale także na całym rynku walutowych instrumentów pochodnych. W latach 2007-2015 udział średnich dziennych obrotów netto na krajowym rynku transakcji forward zawieranych przez te podmioty wynosił od 70\% do 89\% w przypadku krajowego rynku kontraktów forward i od 35\% do 63\% w przypadku krajowego rynku walutowych instrumentów pochodnych. Przede wszystkim wiązało się to ze zwiększoną aktywnością polskich eksporterów, którzy w ten sposób starali się ograniczyć ryzyko kursowe związane z posiadaniem należności w walucie obcej. Potwierdza to zarówno struktura terminowa, jak i walutowa zawieranych transakcji forward. Spadek średnich dziennych obrotów netto o terminie realizacji poniżej 7 dni od 35\% w 2007 roku do 21\% w 2015 roku świadczy o zmniejszeniu aktywności o charakterze spekulacyjnym. Z kolei, walutowa struktura zawieranych transakcji forward wskazuje na 
znaczną przewage pary EUR/PLN nad innymi walutami w całym badanym okresie. Przedsiębiorstwa niefinansowe chciały w ten sposób ograniczyć ryzyko walutowe, wynikające ze zmiany wartości przepływów pieniężnych uzyskanych z wymiany handlowej ${ }^{7}$ na skutek wysokiej zmienności walut [Rožwój..., 2016, s. 308-309].

RYSUNEK 3.

Średnie miesięczne obroty netto na krajowym rynku opcji walutowych oraz transakcji CIRS w latach 2007-2015 (w mld zł)

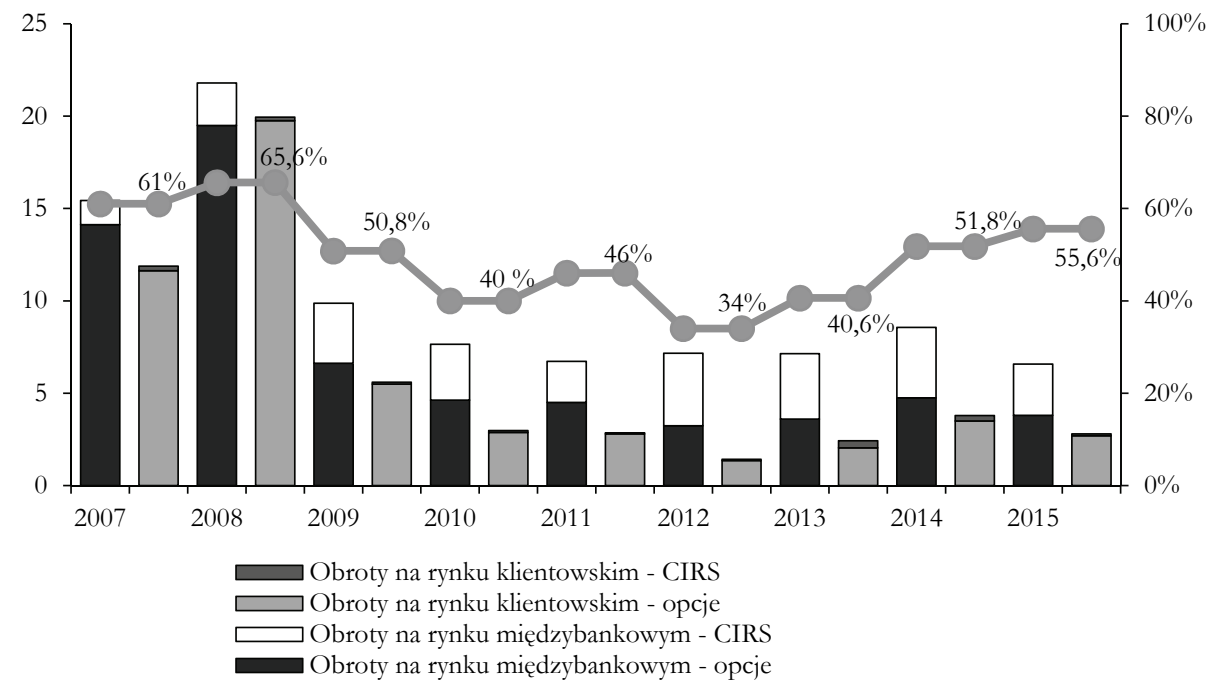

Źródło: opracowanie własne na podstawie danych NBP: [Rozwoój..., 2016, s. 306; Rozwój..., 2013, s. 286; Rozwój..., 2009, s. 244].

Polscy przedsiębiorcy do ograniczenia ryzyka związanego ze zmiennością kursów walutowych również wykorzystywali opcje walutowe i transakcje CIRS, przy czym poziom ich stosowania był znacznie niższy niż kontraktów forward. Ich łączny udział w całości obrotów na krajowym rynku walutowych instrumentów pochodnych po 2009 roku wahał się od 20\% do 30\%. Poza tym, w latach 2007-2015 obroty na międzybankowym rynku opcji walutowych oraz transakcji CIRS przewyższały obroty na rynku klientowskim, co jest widoczne na rysunku 3. Posługiwały się nimi głównie banki i inne instytucje finansowe do zabezpieczania pozycji walutowych. Ta zależność jest wyraźna przede wszystkim na krajowym rynku transakcji CIRS, które były stosowane przez banki do niwelowania

Struktura walutowa zawieranych kontraktów forward wynika ze struktury geograficznej polskiej wymiany handlowej z zagranica - w 2015 roku około 79,4\% eksportu i 60\% importu trafiło do krajów Unii Europejskiej [Rocznik..., 2016, s. 46]. 
ryzyka walutowego i zmiany stóp procentowych na skutek większej ekspozycji tych instytucji na ryzyko związane $\mathrm{z}$ udzielaniem kredytów mieszkaniowych w walutach obcych ${ }^{8}$ [Rozwój..., 2015, s. 301].

$\mathrm{Na}$ krajowym rynku opcji walutowych są zauważalne wahania związane z poziomem wykorzystania tych instrumentów pochodnych przez przedsiębiorstwa do zabezpieczenia się przed ryzykiem walutowym. W okresie od I kwartału 2007 roku do III kwartału 2008 roku występowała tendencja wzrostowa średnich dziennych obrotów netto na tym rynku, głównie w segmencie klientowskim. Zwiększyły się one z 0,56 mld zł w 2007 roku do 0,92 mld zł w 2008 roku, co wiązało się z trwająca od II połowy 2004 roku aprecjacją złotego, która przyczyniła się do wzrostu zainteresowania tymi instrumentami wśród przedsiębiorstw prowadzących wymianę handlową z zagranicą [Rozwój..., 2008, s. 258]. Trend wzrostowy odwrócił się w IV kwartale 2008 roku i nastapił znaczny spadek transakcji zawieranych przez podmioty niefinansowe na rynku opcji walutowych na skutek istotnej deprecjacji złotego. Duża część przedsiębiorstw, które zawarły transakcje opcji walutowych, miała poważne problemy z realizacją wyższych zobowiązań z tytułu ujemnych różnic kursowych, powstałych z racji wyceny i rozliczenia wystawionych opcji call i put. Poza tym, spadek popytu na te instrumenty potęgowała bardziej konserwatywna polityka banków w zakresie zawierania transakcji opcyjnych z przedsiębiorstwami niefinansowymi [Rozwój..., 2009, s. 251].

Negatywne doświadczenia dotyczące konieczności pokrycia zobowiązań wynikających z ujemnej wyceny opcji walutowych spowodowały, że aktywność przedsiębiorstw na tym rynku pozostawała stosunkowo niska. Od 2009 roku miały miejsce tylko okresowe wzrosty obrotów na tym rynku, tj. w III i IV kwartale 2011 roku w związku ze wzrostem zmienności kursów walutowych i silną deprecjacją złotego, a także w I i IV kwartale 2014 roku oraz I i IV kwartale 2015 roku za sprawą wyższych niż w poprzednich okresach wahań kursów walutowych. Poziom wykorzystania opcji walutowych przez przedsiębiorstwa można również ocenić na podstawie terminów realizacji opcji walutowych. W latach: 2007-2008, 2011 i 2014-2015 zawierano transakcje o dłuższych terminach realizacji, tj. powyżej trzech miesięcy. Porównując średnie miesięczne obroty netto ${ }^{9}$ na krajowym rynku opcji walutowych z terminem realizacji transakcji opcyjnych, można zauważyć, iż wraz ze wzrostem obrotów na rynku klientowskim wydłużał się termin realizacji zawartych transakcji, co jest widoczne na rysunku 3. Przedsiębiorstwa zawierały zatem transakcje opcyjne w celu ograniczenia zmienności wyniku finansowego na skutek zmiany wartości należności i zobowiązań powstałych w następstwie prowadzenia wymiany handlowej z zagranicą.

8 Z uwagi na niski udział podmiotów niefinansowych w zawieraniu transakcji CIRS na krajowym rynku walutowych instrumentów pochodnych został on pominięty w analizie w niniejszym artykule.

9 Średnie miesięczne obroty netto na krajowym rynku opcji walutowych i transakcji CIRS oszacowano na podstawie średniej arytmetycznej średnich miesięcznych obrotów netto w poszczególnych kwartałach w latach 2007-2015, udostępnionych przez NBP w raportach o rozwoju systemu finansowego w Polsce. 
TABELA 4.

Rynek giełdowych walutowych instrumentów pochodnych w latach 2007-2015

\begin{tabular}{|c|c|c|c|c|c|c|c|c|c|}
\hline \multirow[b]{2}{*}{ Rok } & \multirow{2}{*}{$\begin{array}{l}\text { Wolumen } \\
\text { obrotu } \\
\text { ogółem } \\
\text { (w mln zf) }\end{array}$} & \multicolumn{3}{|c|}{ W tym: } & \multirow{2}{*}{$\begin{array}{l}\text { Wolumen ob- } \\
\text { rotu ogółem } \\
\text { (w tys. szt.) }\end{array}$} & \multicolumn{3}{|c|}{ W tym: } & \multirow{2}{*}{$\begin{array}{c}\text { Średni } \\
\text { dzienny ob- } \\
\text { rót na sesję } \\
\text { (w mln zł) }\end{array}$} \\
\hline & & $\begin{array}{l}\text { CHF } \\
(\mathrm{w} \%)\end{array}$ & $\begin{array}{l}\text { EUR } \\
(w \%)\end{array}$ & $\begin{array}{l}\text { USD } \\
(\mathrm{w} \%)\end{array}$ & & $\begin{array}{l}\text { CHF } \\
(\mathrm{w} \%)\end{array}$ & $\begin{array}{l}\text { EUR } \\
(\mathrm{w} \%)\end{array}$ & $\begin{array}{l}\text { USD } \\
(w \%)\end{array}$ & \\
\hline 2007 & 332 & 0 & 11,4 & 88,6 & - & bd. & bd. & bd. & 1,34 \\
\hline 2008 & 3612 & 3,9 & 28,7 & 67,5 & 133 & 4,5 & 21,8 & 73,7 & 16,06 \\
\hline 2009 & 5879 & 4,8 & 44,3 & 50,9 & 161 & 5,6 & 36,6 & 57,8 & 23,33 \\
\hline 2010 & 3857 & 6,0 & 23,6 & 70,4 & 120 & 6,7 & 19,2 & 74,2 & 15,24 \\
\hline 2011 & 6646 & 38,2 & 13,9 & 47,8 & 199 & 36,7 & 11,1 & 52,3 & 26,48 \\
\hline 2012 & 5399 & 3,5 & 14,3 & 82,2 & 961 & 2,9 & 11,6 & 85,5 & 21,69 \\
\hline 2013 & 9322 & 3,5 & 9,7 & 86,8 & 2847 & 3,4 & 7,5 & 89,1 & 37,74 \\
\hline 2014 & 7123 & 3,1 & 10,3 & 86,6 & 2175 & 2,9 & 8,0 & 89,1 & 28,61 \\
\hline 2015 & 8293 & 8,2 & 12,9 & 78,9 & 2165 & 7,9 & 11,7 & 80,4 & 33,04 \\
\hline
\end{tabular}

bd. - brak danych

Źródło: opracowanie własne na podstawie danych GPW S.A.: [https://www.gpw.pl/bibliotekagpw-lista?gpwlc_id=10].

Do ograniczenia ekspozycji na ryzyko kursowe przedsiębiorstwa stosują również instrumenty pochodne oferowane przez GPW S.A. Sa to kontrakty futures na trzy pary walut, czyli EUR/PLN, USD/PLN oraz CHF/PLN (tabela 4.). Wykorzystanie tych transakcji pochodnych jest znacznie niższe niż pozagiełdowych instrumentów pochodnych, to natomiast wynika $z$ faktu, iż są one oferowane na rynku regulowanym. Struktura kontraktów futures jest wystandaryzowana, co sprawia, że dopasowanie kwot oraz terminów realizacji tych transakcji do powstałych przepływów pieniężnych w walucie obcej jest trudniejsze niż w przypadku instrumentów pozagiełdowych. Uczestnicy tego rynku to przede wszystkim klienci indywidualni, głównie o nastawieniu spekulacyjnym [Rozwój..., 2016, s. 317]. Wolumen obrotu ogółem, wyrażony wartościowo w poszczególnych latach, wykazywał duże wahania, przy czym od 2007 roku do 2013 roku wzrastała ilość zawieranych transakcji, a w 2014 roku i 2015 roku ilościowy wolumen obrotu ustabilizował się na poziomie około 2,2 mln szt. Widoczna była także znacząca przewaga transakcji futures na kurs USD/PLN. Wiązało się to $z$ większą zmiennością tego kursu walutowego niż kursu EUR/PLN oraz wyższym wykorzystaniem USD w transakcjach gospodarczych niż CHF. 
TABELA 5.

Polscy eksporterzy i importerzy korzystający $z$ instrumentów finansowych w latach 2010-2015

\begin{tabular}{|c|c|c|c|c|c|c|c|c|}
\hline \multicolumn{3}{|c|}{ Wyszczególnienie } & 2010 & 2011 & 2012 & 2013 & 2014 & 2015 \\
\hline \multicolumn{3}{|c|}{ Liczba badanych jednostek } & 1292 & 1292 & 1152 & 1382 & 1404 & 1492 \\
\hline \multicolumn{3}{|c|}{ Przychody ze sprzedaży ogółem (w mld zł) } & 344,1 & 393,9 & 358,7 & 442,1 & 483,8 & 576,1 \\
\hline \multirow{8}{*}{$\begin{array}{l}\frac{ \pm}{0} \\
0 \\
\frac{0}{n} \\
\frac{n}{1 I}\end{array}$} & \multicolumn{2}{|c|}{$\begin{array}{l}\text { Udział eksporterów w badanej zbio- } \\
\text { rowości (w \%) }\end{array}$} & 41,3 & 42,5 & 57,7 & 65,1 & 67,8 & 68,0 \\
\hline & \multicolumn{2}{|l|}{ Wartość eksportu (w mld zł) } & 120,9 & 151,4 & 228,9 & 249,9 & 243,6 & 258,84 \\
\hline & \multicolumn{2}{|c|}{$\begin{array}{l}\text { Udział eksportu w przychodach ze } \\
\text { sprzedaży }(\mathrm{w} \%)\end{array}$} & 35,1 & 38,4 & 63,8 & 56,5 & 50,4 & 44,9 \\
\hline & \multirow{5}{*}{ Struktura walutowa (w \%) } & EUR & 50,2 & 50,7 & 34,1 & 34,1 & 33,7 & 33,3 \\
\hline & & USD & 27,3 & 27,1 & 16,5 & 16,2 & 26,3 & 15,4 \\
\hline & & GBP & 10,8 & 10,8 & 5,7 & 5,5 & 5,6 & 6,3 \\
\hline & & PLN & bd. & bd. & 32,9 & 34,8 & 33,8 & 34,2 \\
\hline & & Inne & 11,7 & 11,4 & 10,8 & 9,4 & 10,6 & 10,7 \\
\hline \multicolumn{3}{|c|}{ Koszty działalności operacyjnej (w mld zł) } & 325,8 & 371,2 & 315,9 & 415,4 & 454,0 & 540,7 \\
\hline \multirow{8}{*}{$\begin{array}{l}\stackrel{ \pm}{0} \\
\text { E् }\end{array}$} & \multicolumn{2}{|c|}{$\begin{array}{l}\text { Udział importerów w badanej zbio- } \\
\text { rowości }(\mathrm{w} \%)\end{array}$} & 43,3 & 44,5 & 60,2 & 68,6 & 71,4 & 72,6 \\
\hline & \multicolumn{2}{|l|}{ Wartość importu (w mld zł) } & 127,97 & 178,5 & 222,8 & 254,8 & 257,3 & 239,5 \\
\hline & \multicolumn{2}{|c|}{$\begin{array}{l}\text { Udział importu w kosztach działal- } \\
\text { ności operacyjnej (w \%) }\end{array}$} & 37,1 & 40,8 & 72,5 & 60,2 & 53,7 & 47,9 \\
\hline & \multirow{5}{*}{ Struktura walutowa (w \%) } & EUR & 55,5 & 54,9 & 32,6 & 31,2 & 31,3 & 31,2 \\
\hline & & USD & 30,3 & 31,0 & 17,7 & 16,9 & 16,7 & 16,6 \\
\hline & & GBP & 14,1 & 13,3 & 6,9 & 10,7 & 11,7 & 13,2 \\
\hline & & PLN & bd. & bd. & 31,6 & 43,0 & 45,6 & 50,2 \\
\hline & & Inne & 14,2 & 14,1 & 12,2 & 14,4 & 14,9 & 14,2 \\
\hline
\end{tabular}

bd. - brak danych

Źródło: opracowanie własne na podstawie danych GUS: [http://stat.gov.pl/].

Oceny wykorzystania instrumentów pochodnych można również dokonać na podstawie danych gromadzonych przez GUS na temat instrumentów finansowych, z których korzystają przedsiębiorstwa w Polsce ${ }^{10}$ (tabela 5.). W latach 2010-2015 zarówno liczba eksporterów oraz importerów, jak i wartość wymiany handlowej z zagranicą uległa zwiększeniu. W 2010 roku udział eksporterów i importerów w badanej zbiorowości wynosił około 40\%, zaś w 2015 roku wzrósł on do poziomu około 70\%. Wzrost liczby podmiotów uczestniczących w handlu zagranicznym spowodował zwiększenie wartości sprzedaży na eksport oraz zakupu dóbr z zagranicy odpowiednio o 214\% i 187\% na przestrzeni badanych sześciu lat. W rezultacie eksport $\mathrm{i}$ import w badanych podmiotach stały się istotnym źródłem przychodów ze sprzedaży oraz kosztów działalności operacyjnej. W przypadku sprzedaży zagranicę udział przychodów z eksportu stanowił od 35,1\%

10 To badanie GUS było prowadzone od 2010 roku wśród przedsiębiorstw, które w kwartalnym sprawozdaniu RF-01 wykazały, że wykorzystują instrumenty finansowe [http://stat.gov.pl/obszary-tematyczne/ podmioty-gospodarcze-wyniki-finansowe/przedsiebiorstwa-niefinansowe/instrumenty-finansowe-przedsiebiorstw-niefinansowych-w-2015-roku,20,5.html]. 
w 2010 roku do 44,9\% w 2015 roku, przy czym był widoczny istotny wzrost tej relacji w latach 2012-2013. Taka sama tendencja była zauważalna w przypadku importu. Jego udział w kosztach działalności operacyjnej wynosił od 37,1\% w 2010 roku do 47,9\% w 2015 roku, a w okresie 2012-2013 relacja wzrosła do ponad 60\%.

Dane na temat struktury walutowej przychodów i kosztów generowanych przez przedsiębiorstwa pokazuja, że głównymi walutami rozliczeń z zagranicą były EUR (około 30\% płatności), USD (około 20\% płatności) i PLN (około 30\%-50\% płatności). Duży udział należności i zobowiązań denominowanych w walutach obcych powodował, że przedsiębiorstwa musiały przyjąć określona postawę wobec ryzyka kursowego. Na przykład podmioty, które są zarówno eksporterami, jak i importerami, mogą ograniczyć ryzyko walutowe za pomocą hedgingu naturalnego ${ }^{11}$, a przedsiębiorstwa zajmujące długą lub krótką pozycję walutową mogą w tym celu wykorzystać instrumenty pochodne.

Informacje na temat instrumentów pochodnych, stosowanych przez przedsiębiorstwa niefinansowe w Polsce, zawiera tabela 6.

TABELA 6.

Wykorzystanie instrumentów pochodnych w polskich przedsiębiorstwach niefinansowych w latach 2010-2015, według GUS

\begin{tabular}{|c|c|c|c|c|c|c|c|c|}
\hline \multicolumn{3}{|c|}{ Wyszczególnienie } & 2010 & 2011 & 2012 & 2013 & 2014 & 2015 \\
\hline \multirow{6}{*}{$\begin{array}{l}\text { Instrumenty } \\
\text { pochodne - } \\
\text { aktywa }\end{array}$} & \multicolumn{2}{|c|}{ Ilość podmiotów } & 145 & 139 & 152 & 296 & 306 & 338 \\
\hline & \multicolumn{2}{|c|}{$\begin{array}{l}\text { Wartość bilansowa ogó- } \\
\text { łem } \\
\text { (w mln zł) }\end{array}$} & 2857,7 & 4230,1 & 3179,0 & 5671,5 & 792,5 & 6615,1 \\
\hline & \multirow{4}{*}{$\begin{array}{l}E \\
E \\
B\end{array}$} & forward (w mln $\mathrm{zl})$ & 969,3 & 1356,4 & 1443,2 & 2852,3 & 843,8 & 4651,6 \\
\hline & & futures (w mln zł) & 4,3 & 9,2 & 7,2 & 11,8 & 97,0 & 82,8 \\
\hline & & opcje (w mln zł) & 170,5 & 540,3 & 958,9 & 1317,4 & 2223,4 & 1470,9 \\
\hline & & pozostałe (w n & 413,3 & 641,1 & 411,3 & 1848,5 & 1311,4 & 1710,1 \\
\hline \multirow{6}{*}{$\begin{array}{l}\text { Instrumenty } \\
\text { pochodne - } \\
\text { pasywa }\end{array}$} & \multicolumn{2}{|c|}{ Ilość podmiotów } & 148 & 177 & 169 & 260 & 340 & 396 \\
\hline & \multicolumn{2}{|c|}{$\begin{array}{l}\text { Wartość bilansowa ogółem } \\
\text { (w mln zł) }\end{array}$} & 5262,7 & 6255,3 & 4752,2 & 3510,3 & 7740,5 & 7026,8 \\
\hline & \multirow{4}{*}{$\begin{array}{l}\ddot{E} \\
\text { 岁 } \\
B\end{array}$} & forward (w $\mathrm{mln} \mathrm{zl}$ ) & 623,5 & 1772,9 & 1476,5 & 1730,4 & 3268,9 & 4010,5 \\
\hline & & futures (w mln $\mathrm{zl}$ ) & 41,3 & 28,7 & 8,2 & 20,8 & 9,0 & 61,4 \\
\hline & & opcje (w mln zł) & 2124,9 & 1058,4 & 383,1 & 93,4 & 251,3 & 294,5 \\
\hline & & pozostałe (w mln zł) & 2473,1 & 2806,7 & 2884,4 & 1665,8 & 4211,3 & 2660,4 \\
\hline \multicolumn{3}{|c|}{$\begin{array}{l}\text { Wynik na inwestycjach w instrumenty } \\
\text { pochodne (w mln zł) }\end{array}$} & $-307,90$ & 477,48 & $-82,65$ & 603,39 & 390,50 & $-30,35$ \\
\hline
\end{tabular}

Źródło: opracowanie własne na podstawie danych GUS: [http://stat.gov.pl/].

11 Hedging naturalny polega na zamknięciu otwartej pozycji walutowej przez zawarcie transakcji przeciwstawnej pod względem: waluty, terminu i wartości [Tymoczko, 2009, s. 74]. 
Stopień wykorzystania instrumentów pochodnych w polskich przedsiębiorstwach niefinansowych zwiększał się, co potwierdził wzrost liczby podmiotów, które wykazywały instrumenty pochodne w swoich sprawozdaniach finansowych. W latach 2010-2015 wartość bilansowa instrumentów pochodnych, wykazywana w sprawozdaniach finansowych, zwiększyła się zarówno po stronie aktywów, jak i pasywów ${ }^{12}$ - odpowiednio o 131,5\% i 33,5\%. Z roku na rok zmniejszała się zatem nadwyżka zobowiązań finansowych nad aktywami finansowymi z tytułu instrumentów pochodnych. Przewaga ujemnej wyceny bilansowej instrumentów pochodnych nie świadczy jednak o stracie wynikającej z rozliczenia takich transakcji, lecz wyłącznie o ich wartości na moment wyceny. Łączny wynik finansowy na inwestycjach w instrumenty pochodne w badanym okresie wyniósł 1,05 mld zł, co może zachęcać podmioty do zabezpieczania się przed ryzykiem za pomocą instrumentów pochodnych.

Dane GUS wskazują również na znaczna przewagę kontraktów forward nad innymi instrumentami pochodnymi. W badanym okresie ich wartość bilansowa po stronie aktywów wzrosła niemal 5-krotnie, a pasywów ponad 6-krotnie. W przypadku opcji walutowych był widoczny spadek ich wykorzystania przez podmioty niefinansowe i wysoka ujemna wartość godziwa tych instrumentów, co wynikało z negatywnych doświadczeń związanych z koniecznościa pokrycia zobowiązań z wyceny opcji walutowych w latach 2008-2009. Większe zaufanie do korzystania z opcji zaczęło pojawiać się od 2013 roku, w którym zwiększała się skala zagranicznej wymiany handlowej, a dodatnia wartość godziwa przewyższała ujemną wartość godziwą tych instrumentów pochodnych. Co więcej, dane GUS potwierdzają niski poziom stosowania kontraktów futures przez podmioty niefinansowe w porównaniu $z$ innymi instrumentami pochodnymi.

Ograniczeniem w badaniach przeprowadzonych w niniejszym artykule jest fakt, iz GUS nie wyodrębnia w zebranych danych informacji na temat wykorzystania walutowych instrumentów pochodnych. Niemniej przeanalizowane dane statystyczne GUS dowodzą, że z roku na rok zwiększa się w równej mierze aktywność polskich przedsiębiorstw na rynkach międzynarodowych, jak i poziom wykorzystania walutowych instrumentów pochodnych. Wyciagnięte wnioski są zatem zgodne $z$ danymi NBP w zakresie skali wykorzystania transakcji pochodnych do zabezpieczenia ryzyka zmian kursów walutowych.

\section{Podsumowanie}

Przeprowadzone badania, dotyczące oceny skali ryzyka kursowego w polskich przedsiębiorstwach oraz wykorzystania walutowych instrumentów pochodnych w latach 20072016, pozwoliły na wyciągnięcie poniższych wniosków.

12 Wartość bilansowa instrumentów pochodnych po stronie aktywów oznacza dodatnią wartość godziwą danego instrumentu pochodnego, a po stronie pasywów ujemną wartość godziwą [Ożga, 2016, s. 277]. Przez wartość godziwą należy rozumieć kwotę, za jaką dany składnik aktywów mógłby zostać wymieniony, zaś zobowiązanie uregulowane na warunkach transakcji rynkowej między zainteresowanymi i dobrze poinformowanymi, niepowiązanymi ze sobą stronami transakcji, np. wartość godziwą kontraktu futures określa się na podstawie różnicy między zabezpieczoną ceną a ceną giełdową w dniu wyceny, natomiast kontraktu forward na podstawie wartości bieżącej przyszłych przepływów pieniężnych generowanych przez instrument pochodny [Ożga, 2016, s. 48-71]. 
1. Wraz ze wzrostem aktywności polskich podmiotów na rynku międzynarodowym, głównie w zakresie eksportu i importu oraz zadłużenia zagranicznego, zwiększa się poziom zabezpieczenia wartości przyszłych płatności denominowanych w walutach obcych przed zmianami kursu złotego.

2. Skala wykorzystania instrumentów pochodnych jest uzależniona od poziomu i wahań kursów walutowych oraz doświadczeń polskich podmiotów w zakresie wykorzystania tych instrumentów.

3. Wyższy poziom wykorzystania pozagiełdowych instrumentów pochodnych w stosunku do giełdowych transakcji pochodnych wskazuje, iż przedsiębiorstwa dostosowują wybrane metody transferu ryzyka kursowego do specyfiki prowadzonej działalności, w tym głównie do warunków zawartych transakcji handlowych i finansowych denominowanych w walutach obcych.

4. Wysoki i stabilny udział kontraktów forward na krajowym rynku walutowych instrumentów pochodnych dowodzi, że przedsiębiorstwa identyfikują powstałe ryzyko walutowe i stosują instrumenty, które są relatywnie zrozumiałe i łatwe do stosowania.

5. Struktura walutowa wybranych instrumentów pochodnych do transferu ryzyka walutowego zależy od struktury walutowej przepływów pieniężnych z tytułu zagranicznej wymiany handlowej oraz zadłużenia zagranicznego.

Analiza literatury przedmiotu oraz przedstawionych danych statystycznych umożliwiła zatem kompleksową ocenę ryzyka walutowego istniejącego w polskich przedsiębiorstwach, co jest szczególnie znaczące w obliczu powszechności występowania tego rodzaju ryzyka. Mogą one dokonać wyboru metody zabezpieczenia się przed zmiennością kursów walutowych spośród wielu instrumentów dostępnych na rynku, w tym również transferu ryzyka za pośrednictwem transakcji pochodnych. Znając korzyści oraz zagrożenia związane z ich stosowaniem, są w stanie wybrać takie narzędzia, które będą dostosowane do specyfiki działalności danego podmiotu i przyczynią się do poprawy jego wyników finansowych.

\section{Wkład autorów w powstanie artykułu}

mgr Magdalena Tekień - opracowanie koncepcji oraz wybór metody do badań, zebranie materiału statystycznego, opracowanie części teoretycznej (rozdział 1 i 3), współudział w opracowaniu wyników (rozdział 2 i 5), pozostałe (m.in. dostosowanie do wymogów technicznych) $-55 \%$,

dr Katarzyna Lewkowicz-Grzegorczyk - opracowanie koncepcji oraz wybór metody do badań, zebranie materiału statystycznego, opracowanie części teoretycznej (rozdział 4), współudział w opracowaniu wyników (rozdział 5) - 45\%.

\section{Literatura}

Bennett D., 2000, Ryzyke walutowe - instrumenty i strategie zabezpieczajace, Dom Wydawniczy ABC, Warszawa. 
http://stat.gov.pl/ (data wejścia: 06.04.2017).

http://stat.gov.pl/obszary-tematyczne/podmioty-gospodarcze-wyniki-finansowe/ (data wejścia: 05.04.2017).

http://swaid.stat.gov.pl/SitePagesDBW/HandelZagraniczny.aspx (data wejścia: 05.04.2017).

http://www.nbp.pl/home.aspx?c=/ascx/koniunktura_prezentacja.ascx (data wejścia: 06.04.2017).

http://www.nbp.pl/home.aspx?f=/kursy/arch_a.html (data wejścia: 03.04.2017).

https://www.gpw.pl/biblioteka-gpw-lista?gpwlc_id=10 (data wejścia: 24.03.2017).

Kalinowski M., 2012, Ryzyko walutowe, Wydawnictwo CeDeWu.pl, Warszawa.

Loderer C., Pichler K., 2000, Firms, do you know your currency risk exposure? Survey results, "Journal of Empirical Finance", no. 7.

Miciuła I., 2015, Methods for providing economic safety in business transactions in the context of currency risk, Prace Naukowe Uniwersytetu Ekonomicznego we Wrocławiu, nr 412.

Misztal P., 2004, Zabezpieczenie przed rysylkiem żmian kursu walutowego, Wydawnictwo Difin, Warszawa.

Ożga P., 2016, Rachunkowosś instrumentón pochodnych, Wydawnictwo C.H. Beck, Warszawa. Raport o stabilności systemu finansowego, 2016, NBP, Warszawa.

Rocznik statystyczny handlu zagranicznego 2016, 2016, GUS, Warszawa.

Rozporzadzenie Ministra Finansów z.dnia 12 grudnia 2001 roku w sprawie szcrzegótonych zasad uznawania, metod wyceny, zakresu ujawniania i sposobu prezentaci instrumentów finansonych, Dz. U. 2001, Nr 149, poz. 1674.

Rozwój systemu finansowego w Polsce w 2007 r., 2008, NBP, Warszawa. Rozwój systemu finansowego w Polsce w 2008 r., 2009, NBP, Warszawa. Rozwój systemu finansowego w Polsce w 2009 r., 2010, NBP, Warszawa. Rozipój systemu finansowego w Polsce w 2010 r., 2011, NBP, Warszawa. Rozwój systemu finansowego w Polsce w 2011 r., 2012, NBP, Warszawa. Rozwó́j systemu finansowego w Polsce w 2012 r., 2013, NBP, Warszawa. Rozwój systemu finansowego w Polsce w 2013 r., 2014, NBP, Warszawa. Rozwó́j systemu finansowego w Polsce w 2014 r., 2015, NBP, Warszawa. Rozwój systemu finansowego w Polsce w 2015 r., 2016, NBP, Warszawa.

Sudacevschi M., 2017, Foreign currency risk hedging, "Challenges of the Knowledge Society", no. 7.

Szyszko L., 2003, Pojecie i organizacja finansów przedsiebiorstwa, [w:] Finanse przedsiebiorstwa, L. Szyszko, J. Szczepański (red.), Polskie Wydawnictwo Ekonomiczne, Warszawa. Triennial Central Bank Survey of foreign exchange and OTC derivatives markets in 2016, 2016, BIS, Basel.

Tymoczko I., 2009, Sposoby zabezpieczania sie polskich przedsiebiorstw niefinansonych przed rysykiem kursonym, „Bank i Kredyt”, nr 40 (3).

Ustawa z. dn. 29.07.2005 roku o obrocie instrumentami finansonymi, Dz. U. 2005, Nr 183, poz. 1538.

Widz E., 2012, Wykorsystanie kontraktów futures do zabezpieczania eksposycji na ryzylko walutowe, „Annales Universitatis Mariae Curie-Skłodowska, sectio H - Oeconomia”, nr 46 (2012), 1. 